\title{
State Management of the Sphere of Circulation of Medicines in the Context of the COVID-19 Pandemic
}

\author{
Yerik B. Bukatov ${ }^{1 *}$, Galiya I. Gimranova ${ }^{1}$, Sergey A. Shanin ${ }^{2}$ \\ ${ }^{1}$ Karaganda university of Kazpotrebsoyuz, , Str. Academic 9, 100009, Karaganda, Kazakhstan, \\ ${ }^{2}$ Plekhanov Russian University of Economics, 117997, Moscow, Russia
}

\begin{abstract}
This article analyzes the state management of the sphere of circulation of medicines in the Republic of Kazakhstan in the context of the COVID-19 pandemic, and analyzes the reasons for the shortage of medicines in the specified period. The authors conducted a sociological survey, which made it possible to identify the main problems faced by the population during the COVID-19 pandemic. All major players in the pharmaceutical market of the Republic of Kazakhstan are analyzed. The activity of «SK-Pharmacy» during the COVID-19 pandemic was considered, and measures aimed at eliminating ineffective management identified in the work of a single distributor of medicines were analyzed. The measures of the state to reduce prices for essential medicines during a pandemic are considered. Based on domestic and foreign experience, an analysis of external reference pricing for medicines was carried out. The expenditures of the population on health care, including on medicines, were considered. The study resulted in the proposed measures to improve public administration in the sphere of drug circulation in the Republic of Kazakhstan. It is concluded that the state needs to take several measures in the field of drug circulation to prevent a possible shortage of pharmaceuticals and contain drug prices during future pandemics. It is necessary to increase funding for the health care system, including for medicines, without shifting the financial burden on the population and employers. It is necessary to build an effective system of pricing for medicines, which would consider the peculiarities of the global and Kazakhstani pharmaceutical market.
\end{abstract} tures.

Keywords: Public administration, pandemic, medicines, health care system, drug pricing, household expendi-

For citation: Bukatov, Y.B. , Gimranova, G.I. \& Shanin, S.A. (2021). State Management of the Sphere of Circulation of Medicines in the Context of the COVID-19 Pandemic. Economics: the Strategy and Practice, 16(3), 227-242, https://doi.org/10.51176/1997-9967-2021-3-227-242

* Corresponding author: Yerik B. Bukatov - doctoral student, Karaganda university of Kazpotrebsoyuz, Republic of Kazakhstan, 100009, Karaganda, Str. Academic 9, +87001417765, e-mail: bukatov.erik@mail.ru

Conflict of interests: the authors declare that there is no conflict of interest

Financial support: The study was not sponsored (own resources).

Acknowledgments. We express our gratitude to the doctor of the polyclinic No. 4 in Karaganda, Rakhimberlina Saltanat Ardakovna for her help in conducting a sociological survey.

The article received: 25.06 .2021

The article approved for publication: 21.07. 2021

Date of publication: 30.09 .2021 


\title{
COVID-19 пандемиясының жағдайында дәрілік заттар айналымы саласын мемлекеттік басқару
}

\author{
Букатов Е.Б. ${ }^{*}$, Гимранова Г.И. ${ }^{1}$, Шанин С.А. ${ }^{2}$ \\ ${ }^{1}$ Қазтұтынуодавы Қараванды университеті, Академиялық 9 көшесі, 100009, Қараванды, \\ Қазақстан, \\ ${ }^{2}$ Г.В. Плеханов атындавы Ресей экономикалық университеті, 117997, Мәскеу, Ресей
}

\begin{abstract}
Түйін
Бұл мақалада COVID-19 пандемиясы жағдайында Қазақстан Республикасындағы дәрі-дәрмектер айналымы саласын мемлекеттік басқару талданып, көрсетілген мерзімде дәрілік заттардың жетіспеу себептері талданды. Авторлар COVID-19 пандемиясы кезінде халықтың алдында тұрған негізгі мәселелерді анықтауға мүмкіндік беретін әлеуметтік сауалнама жүргізді. Қазақстан Республикасының фармацевтикалық нарығының барлық негізгі қатысушылары талданды. COVID-19 пандемиясы кезінде «СК-Фармация» қызметі қаралды, сондай-ақ дәрілік заттардың бірыңғай дистрибьюторының жұмысында анықталған тиімсіз басқаруды жоюға бағытталған шаралар талданды. Пандемия кезеңінде негізгі дәрілік заттардың бағасын төмендету жөніндегі мемлекеттік шаралар қаралды. Отандық және шетелдік тәжірибе негізінде дәрілік заттарға сыртқы референттік баға белгілеуге талдау жүргізілді. Сондай-ақ, халықтың денсаулық сақтауға, оның ішінде дәрілік заттарға арналған шығыстары қаралды. Зерттеудің нәтижесі Қазақстан Республикасында дәрілік заттар айналымы саласындағы мемлекеттік басқаруды жетілдіру бойынша ұсынылған шаралар болды. Мемлекет фармацевтикалық препараттардың ықтимал тапшылығын болдырмау және болашақ пандемия кезеңінде дәрілік заттардың бағасын ұстап тұру үшін дәрілік заттар айналымы саласында бірқатар шаралар қабылдауы қажет деген қорытынды жасалды. Мемлекет қаржылық ауыртпалықты халық пен жұмыс берушілерге жүктемей, денсаулық сақтау жүйесін қаржыландыруды ұлғайтуы қажет. Әлемдік және қазақстандық фармацевтика нарығының ерекшеліктерін ескеретін дәрілік заттарға баға белгілеудің тиімді жүйесін құрған жөн.
\end{abstract}

Түйін сөздер: Мемлекеттік басқару, пандемия, дәрілер, денсаулық сақтау жүйесі, дәрілік заттарға баға белгілеу, үй шаруашылықтарының шығыстары.

Дәйексөз алу үшін: Букатов Е.Б., Гимранова Г.И., Шанин С.А. (2021). COVID-19 пандемиясының жағдайында дәрілік заттар айналымы саласын мемлекеттік басқару. Экономика: стратегия және практика, 16(3), 227-242, https://doi.org/10.51176/1997-9967-2021-3-227-242

* Хат-хабаршы авторы: Букатов Е.Б. - докторант, Қазтұтынуодағы Қарағанды университеті, 100009 , Қарағанды қаласы, Академиялық 9 к., Қазақстан, +87001417765, e-mail: bukatov.erik@mail.ru

Мүдделер қақтығысы: авторлар мүдделер қақтығысының жоқтығын мәлімдейді.

Қаржыландыру. ерттеу демеушілік қолдау көрсеткен жоқ (меншікті ресурстар).

Алғыс айту. Қарағанды қаласының №4 емханасының дәрігері Рахимберлина Салтанат Ардаковнаға әлеуметтік сауалнама жүргізуге көмектескені үшін алғысымызды білдіреміз.

Мақала редакцияға түсті: 25.06 .2021

Жариялау туралы шешім қабылданды: 21.07.2021

Жарияланды: 30.09 .2021 


\title{
Государственное управление сферой обращения лекарственных средств в условиях пандемии COVID-19
}

\author{
Букатов Е.Б. ${ }^{*}$, Гимранова Г.И. ${ }^{1}$, Шанин С.А. ${ }^{2}$ \\ ${ }^{1}$ Карагандинский университет Казпотребсоюза, 100009, г. Караганда, ул. Академическая, 9, \\ Казахстан, \\ ${ }^{2}$ Российский экономический университет им. Г.В. Плеханова, 117997, Москва, Россия
}

\begin{abstract}
Аннотация
В настоящей статье проанализировано государственное управление сферой обращения лекарственных средств в Республике Казахстан в условиях пандемии COVID-19, а также проанализированы причины возникновения дефицита лекарственных средств в указанный период. Авторами был проведен социологический опрос, позволивший выявить основные проблемы, с которыми столкнулось население во время пандемии COVID-19. Проанализированы все основные участники фармацевтического рынка Республики Казахстан. Рассмотрена деятельность «СК-Фармация» во время пандемии COVID-19, а также проанализированы меры, направленные на устранение неэффективного управления, выявленные в работе единого дистрибьютора лекарственных средств. Рассмотрены меры государства по снижению цен на основные лекарственные средства в период пандемии. На основе отечественного и зарубежного опыта, произведен анализ внешнего референтного ценообразования на лекарственные средства. Были рассмотрены расходы населения на здравоохранение, в том числе и на лекарственные средства. Результатом исследования стали предложенные меры по совершенствованию государственного управления сферы обращения лекарственных средств в Республике Казахстан. Сделан вывод о том, что государству необходимо предпринять ряд мер в сфере обращения лекарственных средств для недопущения возможного дефицита фармацевтических препаратов и сдерживания цен на лекарственные средства в период будущих пандемий. Необходимо увеличить финансирование системы здравоохранения, в том числе и на лекарственные средства, не перекладывая финансовое бремя на население и работодателей. Следует выстроить эффективную систему ценообразования на лекарственные средства, которая учитывала бы особенности мирового и казахстанского фармацевтического рынка.
\end{abstract}

Ключевые слова: Государственное управление, пандемия, лекарственные средства, система здравоохранения, ценообразование на лекарственные средства, расходы домашних хозяйств.

Для цитирования: Букатов Е.Б., Гимранова Г.И., Шанин С.А. (2021). Государственное управление сферой обращения лекарственных средств в условиях пандемии COVID-19. Экономика: стратегия и практика, 16(3), 227-242, https://doi.org/10.51176/1997-9967-2021-3-227-242

* Корреспондирующий автор: Букатов Е.Б. - докторант, Карагандинский университет Казпотребсоюза, Республика Казахстан, 100009, г. Караганда, ул. Академическая 9, +87001417765, e-mail: bukatov.erik@mail.ru

Конфликт интересов: авторы заявляют об отсутствии конфликта интересов.

Финансирование. Исследование не имело спонсорской поддержки (собственные ресурсы).

Благодарность. Выражаем благодарность врачу поликлиники №4 г. Караганды, Рахимберлиной Салтанат Ардаковне за помощь в проведении социологического опроса.

Статья поступила в редакцию: 25.06 .2021

Принято решение о публикации: 21.07 .2021

Опубликовано: 30.09 .2021 


\section{Введение}

Лекарственные средства играют важную роль в жизни человека, общества и государства. Лекарства позволяют снижать уровень заболеваемости, улучшать здоровье, продлевать жизнь, смягчать течение болезни тяжелобольных пациентов, снижать количество летальных исходов и т.д. Всемирная пандемия COVID-19 показала, что лекарственные средства имеют стратегическое значение для многих государств мира, в том числе и для Казахстана. Во время пандемии, перед казахстанской системой здравоохранения была поставлена задача по оперативному обеспечению населения необходимыми лекарственными средствами. Национальная безопасность страны, жизнь и здоровье казахстанцев зависела и зависит от эффективного государственного управления сферой обращения лекарственных средств. В рамках данной статьи были рассмотрены и проанализированы государственные меры по преодолению негативных последствий пандемии в сфере обращения лекарственных средств. Целью данной статьи является рассмотрение совокупности мер государственного управления сферой обращения лекарственных средств. В данной статье были использованы общенаучные и эмпирические методы исследования.

\section{Литературный обзор}

Теоретические и практические аспекты государственного управления сферой обращения лекарственных средств широко представлены в трудах отечественных и зарубежных ученных. Так Т. Боченек, В. Абилова, А. Алкан, Б. Асанин, М. Бериан и др., рассматривали проблему нехватки лекарств в 28 странах Европы и Западной Азии [1]. В рамках исследования рассматривались законодательные и организационные аспекты, а также системные меры по уменьшению и предотвращению нехватки лекарственных средств. На глобальном уровне проблему нехватки лекарственных средств рассматривали Акоста А., Ванегас П., Ровира Д., Годман Б. и др. [2].

Вопросы глобальной нехватки лекарств из-за COVID-19, а также влияние этой проблемы на лечение пациентов и ее последствия отражены в исследовании $\mathrm{X}$. Бадрелдина и Б. Аталлаха [3]. Решение проблем нехватки лекарств предложены в перекрестном исследовании, проведенном в 24 странах Фоглер С. и Фишером С. [4]. Проблемы нехватки жизненно важных лекарств во время пандемии COVID-19 рассмотрены в трудах Шумана Э.Г., Фокс Э., Унгуру Й. [5].

Влияние государственного управления на некачественные и фальсифицированные лекарства в Китае, Индонезии, Турции и Румынии описано группой ученных Э. Пизани, А.Л. Нистор, К. Пармаксиз и др. [6]. Государственное влияние и проблемы фальсифицированных лекарств в Казахстане показаны в работе К.А. Зординовой, М.Ж. Ташкеевой, Г.М. Гуламовой [7].

Учитывая функционирование единого фармацевтического рынка Евразийского экономического союза (ЕАЭС), особый интерес вызывают работы исследователей из данных стран. Проблемы интеграции фармацевтических рынков и особенности государственного управления сферой обращения лекарственных средств стран ЕАЭС были рассмотрены в работах Торопыгина А.В. [8], Торегожиной М.Б., Егизбаевой Ж.Т. [9], Марцевой Т.Г., Воблая И.Н., Сейфиевой Е.Н. [10], Бортниковой А.П. [11], Дюсембиновой Г.А., Искаковой Б.З., Серикбаевой Э.А., Дошмановой С.Д. [12] и др.

Воздействие последствий пандемии COVID-19 на экономические и социальные процессы и влияние государственных мер на пандемию, показаны в работах Джилиссена Э., Маллигана К., Тоттмана С., Троена П. [13], Акимова А.В. [14], Маллаха С.И., Гораба О.К., Аль-Салми С., Абделлатифа О.С., Фармаратнама Т., Искандара М.А., Сефена Дж., Сидху П., Эль-Лабабиди Р., Аль-Кахтани М. [15], Хауга Н., Гейрхофера Л., Лондеи А., Дервич Э., Десвар-Ларрив А., Лорето В., Пиниора Б., Турнера С., Климека П. [16], Браунера Дж.М., Миндерманна С., Шарма М., Джонстон Д., Сальватье Дж. [17], Шаха С., Рэйа Б., Холи К., Сакхивела М., Элангованрааджа Н., Кришнана Д., Гупта С., Триведи П., Девулапалли М., Мохапатра А. , Коплана П. [18] и др. Обеспечение лекарственной независимости во время пандемии COVID-19 рассмотрены в работе Терещенко А.П. [19].

Из казахстанских ученых определенный интерес вызывают работы Сатаевой Л.Г., Мырзабаевой Н.А., Шопабаевой А.Р., Шукирбековой А.Б., Жакипбекова К.С., Сагантаевой С.X., Мухамеджановой 3. [20], Жусуповой Г.К., Есбатыровой Л.М., Байдуллаевой Д.К., Калиевой Ш.С [21], Алиевой Н.А., Манап А.С., Исабаева М.М [22], Кульжанова М.К., Жантуриева Б.М., Надырова П.Т., Датхаева У.М. [23], Спанова М.У., Орынбет П.Ж. [24] и др., раскрывающие особенности государственного управления сферой обращения лекарственных средств. 


\section{Методология}

Исследование проведено на основе признанных научных методов, системного и комплексного подхода, а также на основе социологических и статистических методов исследования. $\mathrm{C}$ помощью структурнофункционального и институционального подходов проведена оценка сферы обращения лекарственных средств. Был проведен анализ внешнего референтного ценообразования на лекарственные средства и проанализированы основные участники фармацевтического рынка в Республике Казахстан. В исследовании использованы качественные и количественные методы оценки на основе динамики цен на лекарственные средства, производства фармацевтической продукции, рейтинговой оценке участников сферы обращения лекарственных средств. В качестве информационной базы использованы нормативноправовые акты Республики Казахстан, ЕАЭС и Европейского Союза в сфере обращения лекарственных средств, официальные данные Министерства здравоохранения Республики Казахстан, Республиканского центра развития здравоохранения, ТОО «СК-Фармация», Комитета медицинского и фармацевтического контроля, Бюро национальной статистики Агентства по стратегическому планированию и реформам Республики Казахстан и Всемирной организации здравоохранения. Также научной базой исследования послужили труды зарубежных и отечественных ученых, посвящённых государственному управлению сферой обращения лекарственных средств.

Кроме того, в ходе социологического опроса, были получены данные по лекарственному обращению во время пандемии COVID-19 в Республике Казахстан. Социологический опрос проводился на базе поликлиники №4 города Караганды. Респондентам было задано два основных вопроса, связанных с дефицитом лекарственных средств во время пандемии COVID-19 и возникающими проблемами при приобретении лекарственных средств. В опросе участвовало 302 человека - 75,2\% женщин; $24,8 \%$ мужчин, средний возраст респондентов $(74,5 \%)$ составлял от 25 до 63 лет. Стоит отметить, что согласно исследованию компании «Dosmart» основным покупателем лекарственных средств в РК являются женщины (87\% продаж), средний возраст покупателей составляет 36-50 лет. Проведенный нами опрос, также показывает схожие проблемы, связанные с выборкой респондентов. Полученные данные свидетельствуют о том, что мужчины меньше посещают медицинские и аптечные учреждения, чем женщины.

\section{Результаты и обсуждение}

Всемирная пандемия COVID-19 негативно отразилась на всем человечестве, по данным на 23 июня 2021 года количество официальных жертв превысило 3,88 миллиона человек, а число заболевших превысило 179 миллиона человек. ${ }^{1}$ С начала пандемии COVID-19, по данным Министерства здравоохранения в Республике Казахстан умерло 4261 человек, всего заболело 411771 тыс. человек, выздоровели 387295 тыс. человек. ${ }^{2}$ В 2020 году резко выросла смертность среди казахстанцев, в том числе и по причине прямого и косвенного воздействия пандемии COVID-19. Так, смертность в Казахстане в 2015 году составила - 131,8 тыс. чел., в 2016 году - 131,2 тыс. чел., в 2017 году - 129 тыс. чел., в 2018 году - 130,4 тыс. чел., в 2019 году - 133,4 тыс. чел., в 2020 году - 162,6 тыс. чел. В 2020 году меньше всего казахстанцев умерло в карантин, в марте -8 511 тыс. чел., в апреле - 4141 тыс. чел. После смягчения карантинных мер смертность резко выросла, в мае - 14358 тыс. чел., в июне 14 949 тыс. чел., и достигла своего пика в июле 28178 тыс. чел. Начиная с августа, смертность начала снижаться: в августе - 17835 тыс. чел., в сентябре - 13672 тыс. чел., в октябре - 12489 тыс. чел., в ноябре - 12388 тыс. чел., в декабре - 13083 тыс. чел. ${ }^{3}$

Системы здравоохранения многих стран, как развитых, так и развивающихся, испытали колоссальные нагрузки вследствие быстрого распространения коронавирусной инфекции. Многие государства, в том числе и Республика Казахстан, столкнулись также и с дефицитом лекарственных средств во время острой фазы распространения пандемии COVID-19. Дефицит лекарственных средств повлиял на смертность населения и повысил социальные риски среди незащищенных слоев населения. В ходе исследования, нами был проведен социологический опрос потребителей лекарственных средств в поликлинике №4 г. Караганды. В опросе приняли участие

1 Всемирная организация здравоохранения. [Электронный ресурc]. URL: https://www.who.int/ ru (дата обращения: 23.06.2021)

2 Министерство здравоохранения Республики Казахстан. [Электронный ресурс]. URL: https:// www.gov.kz/memleket/entities/dsm?lang=ru (дата обращения: 23.06.2021).

3 Бюро национальной статистики Агентства по стратегическому планированию и реформам Республики Казахстан. [Электронный ресурс]. URL: https://stat.gov.kz/ (дата обращения: 20.02.2021). 
302 респондента, наибольшее количество респондентов относились к возрастной группе 35-63 лет (113 человек), 25-34 лет (112 человек), 18-24 лет (63 человек), 63 и более лет (14 человек). В опросе приняли участие 227 женщин и 75 мужчин. Из опрошенных: работали - 204 человек; были студентами -
50 человек, были пенсионерами - 21 человек; не работали - 14 человек; выбрали вариант другое - 13 человек. 302 респондентам был задан вопрос, сталкивались ли Вы с дефицитом лекарственных средств во время пандемии COVID-19 (рисунок 1).

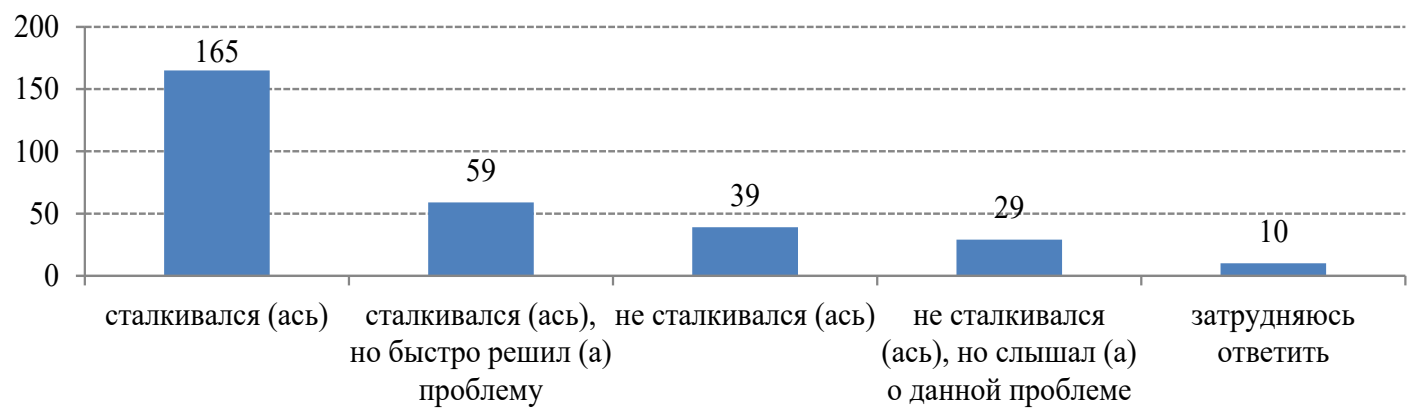

Рисунок 1 - Социологический опрос: сталкивались ли Вы с дефицитом лекарств во время пандемии COVID-19

Figure 1-Opinion poll: Have you experienced a shortage of medicines during the COVID-19 pandemic

Примечание - Составлено авторами.

Так большинство респондентов, 165 человек столкнулись с дефицитом лекарств во время пандемии COVID-19. Из опрошенных респондентов 59 столкнулись с дефицитом лекарств, но быстро решили данную проблему. Не сталкивались с дефицитом лекарств 39 человек, не сталкивались, но слышали о данной проблеме 29 человек и 10 человек затруднились ответить на данный вопрос.

Также респондентам был задан вопрос, какие проблемы больше всего Вас беспокоят при поиске и приобретении лекарств (несколько вариантов ответа) (рисунок 2).

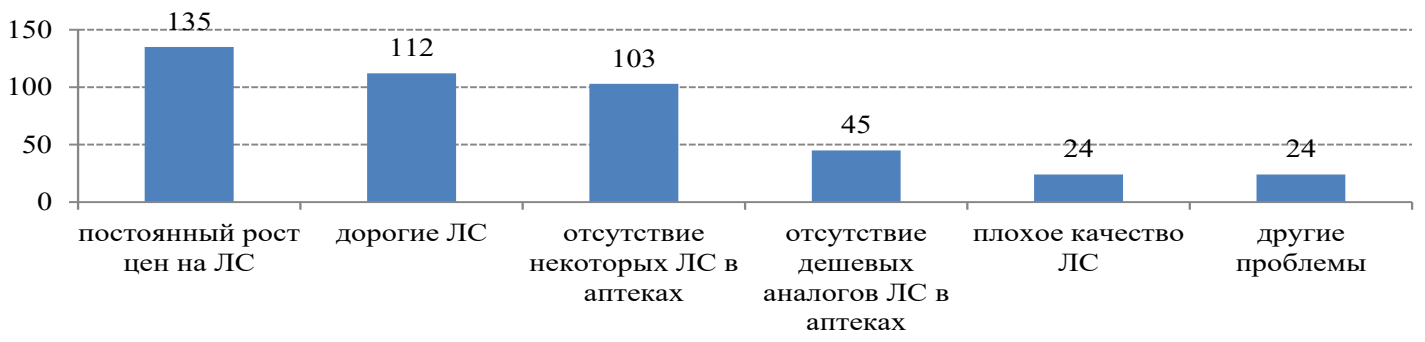

Рисунок 2 - Социологический опрос: основные проблемы при поиске и приобретении лекарств

Figure 2 - Sociological survey: the main problems in the search and purchase of medicines

Примечание - Составлено авторами.

В результате опроса, удалось выявить, что 135 человек больше всего беспокоит постоянный рост цен на лекарственные средства. Наличие в аптеках дорогих лекарств беспокоит 112 человек, отсутствие необходимых лекарств в аптеках беспокоит 103 респондента. Для 45 респондентов отсутствие дешевых аналогов лекарств в аптеках является важной проблемой, на плохое качество пожаловались 24 респондента и столько же указало на другие проблемы связанные с поиском и приобретением лекарственных средств. 
Таким образом во время пандемии COVID-19 казахстанцы столкнулись с проблемой дефицита лекарственных средств и их высокой стоимостью. Проблема высоких цен на лекарственные средства характерна для Казахстана уже многие годы, в 2015 году уровень инфляции на лекарственные средства составил 31,3\%; в 2016 году - 17,7\%; в 2017 году - 6,6\%; в 2018 году - 7,8\%; в 2019 году $6,2 \%$; в 2020 году $-9,9 \% .^{3}$ В условиях пандемии COVID-19 государственное управление сферой обращения лекарственных средств было направлено на обеспечение населения основными недорогими антиковидными лекарственными средствами.

Согласно рекомендациям Всемирной Организации Здравоохранения (ВО3), для обеспечения национальной лекарственной безопасности, каждая страна должна производить $30 \%$ потребляемых лекарственных средств в денежном выражении. Республика Казахстан с обретением независимости стремится обеспечить свою лекарственную безопасность, стоит отметить что в составе Советского Союза, Казахстан в основном обеспечивался лекарствами Союзными Республиками, имея незначительное фармацевтическое производство. В 1997 году Казахстан начал реализацию программы развития фармацевтической и медицинской промышленности. С 1997 года доля казахстанских производителей на фармацевтическом рынке в денежном выражении выросла с 3\% до 10\% в 2009 году. ${ }^{4}$ При помощи программы по развитию фармацевтической промышленности Республики Казахстан на 2010-2014 годы и комплексного плана по развитию фармацевтической и медицинской промышленности на 2015-2019 годы, казахстанским производителям удалось увеличить долю на фармацевтическом рынке до $17 \%$ в денежном выражении и до $39 \%$ в натуральном выражении. В 2020 году началась реализация комплексного плана по развитию фармацевтической и медицинской промышленности на 2020-2025 годы, согласно указанному плану, казахстанские производители должны увеличить долю на рынке до 30\% в денежном выражении и до 50\% в натуральном выраже-

\footnotetext{
4 Программа по развитию фармацевтической промышленности Республики Казахстан на 2010-2014 годы (Постановление Правительства Республики Казахстан от 4 августа 2010 года № 791). [Электронный pecypc]. URL: https://adilet. zan.kz/rus/docs/P100000791_(дата обращения: 02.15.2021).
}

нии. ${ }^{5}$ Реализация указанных целей, позволит Казахстану снизить импортную зависимость в сфере лекарственных средств, а также положительно скажется на ценообразовании фармацевтической продукции.

Развивая фармацевтический рынок, государство должно не забывать о честной конкуренции среди участников рынка. Всемирная пандемия COVID-19 показала наличие на казахстанском фармацевтическом рынке среди участников картельных сговоров и монополий. В 2020 году на территории страны было зарегистрировано 33 производителя лекарственных средств, 17 производителей выпускали лекарства по стандартам GMP (надлежащая производственная практика). Из всех казахстанских производителей лекарств только АО «Химфарм» и «Нобел Алматинская Фармацевтическая Фабрика» представлены в ТОР-15 ведущих фармацевтических корпораций Казахстана, остальные компании являются иностранными производителями. AO «Химфарм» занимает 6,4\% доли рынка, «Нобел Алматинская Фармацевтическая Фабрика» занимает 4,5\% доли рынка. ${ }^{6}$ Всего 6 из 33 производителей, вместе производят 77\% всех лекарственных средств в Казахстане. К ведущим казахстанским производителям также можно отнести: ТОО «Карагандинский фармацевтический комплекс», ТОО «Абди Ибрахим», ТОО «Kelun-Kazpharm», ТОО «DOSFARM». В период пандемии казахстанские компании произвели лекарств на 138,3 млрд.тенге, реальный рост производства лекарств составил 47\%. В то же время выросла доля импорта, если в январе 2020 года Казахстан импортировал лекарства на сумму 72,1 млн. USD, то в январе 2021 года этот показатель вырос до 423 млн. USD. В 2019 году объем импорта составил 1,146 млрд. USD, в период пандемии импорт вырос до 1,229 млрд. USD. ${ }^{7}$ Во многом, зависимость от импорта способствует появлению дефицита лекарств и подверженности цен внешнему влиянию.

\footnotetext{
5 Об утверждении Комплексного плана по развитию фармацевтической и медицинской промышленности на 2020-2025 годы (Распоряжение Премьер-Министра Республики Казахстан от 6 октября 2020 года № 132-p). [Электронный pecypc]. URL: https://adilet.zan. kz/rus/docs/R2000000132 (дата обращения: 02.15.2021).

6 Аутсорсинговая компания IQVIA. Динамика фармрынка России и СНГ в 2018, 2019, 2020 годах. Электронный ресурc]. URL: https://www. iqvia.com/(дата обращения: 23.05.2021).

7 АО «Казахстанский центр индустрии и экспорта «Qazindustry». [Электронный ресурс]. URL: https://qazindustry.gov.kz/docs/otchety/1581932380. pdf (дата обращения: 14.03.2021).
} 
Среди более 2 тысяч компаний занимающихся дистрибуцией лекарств, можно выделить 6 крупных компаний [26]. Данные компании занимают на розничном рынке следующие доли: TOO «INKAR» 21,5\%; ТОО «Аманат» 20,9\%; ТОО «Медсервис плюс» 17,1\%; ТОО «Эмити Интернешнл» 9\%; ТОО «Стофарм» 8,7\%; ТОО «Ак Ниет» $7,6 \%{ }^{8}$ Контрагентами «СК-Фармация», оказывающими логистические услуги являются «Стофарм», «Ак Ниет» и «Медсервис плюс». Во время пандемии в связи с форс-мажорными обстоятельствами, к указанным компаниям присоединилась компания «INKAR», которая взяла на себя обязательства по доставке необходимых лекарств в регионы Казахстана. Стоит отметить, что кроме вышеуказанных компаний, в системе закупок «СК-Фармация» участвуют производители лекарств и международные компании. Например: Химфарм, Pfizer, Нобел АФФ, КазБелМедФарм, Карагандинский фармацевтический комплекс, ЮНИСЕФ и т.д.9

В 2020 году в Казахстане функционировало более 8 тысяч аптек, среди них были как единичные аптеки, так и крупные аптечные сети. Среди крупных аптечных сетей можно выделить: EuroPharma, Биосфера, Цветная, Аманат, Pharmacom. C внедрением стандартов GPP (надлежащая аптечная практика) количество аптек возможно будет сокращаться, потому что не все единичные аптеки имеют ресурсы перейти на указанные стандарты. Количество крупных аптечных сетей наоборот будет увеличиваться, так как они имеют возможности соответствовать мировым стандартам.

Таким образом, в Казахстане за годы независимости сформировались основные участники фармацевтического рынка. При большом количестве участников, в каждом сегменте рынка есть 5-6 компаний, которые занимают лидирующее положение и определяют развитие рынка. В разные годы, лидирующие компании, такие как Стофарм, Медсервис плюс, КазБелМедФарм были признаны участниками недобросовестной конкуренции. В 2017 году «СК-Фармация» была оштрафована на 1,3 млрд. тенге за создание монопольных условий компании «Стофарм» в

\footnotetext{
8 Консалтинговое агентство «Vi-Ortis». [Электронный ресурc]. URL: https://www.viortis. kz/(дата обращения: 12.04.2021).

9 Годовой отчет Единого дистрибьютора за 2020 год («СК-Фармация»). [Электронный ресурс]. URL: https://sk-pharmacy.kz/rus/about/otchetnost (дата обращения: 9.03.2021).
}

2010-2015 годах. ${ }^{10}$ Поэтому государственные и квазигосударственные органы должны препятствовать недобросовестной конкуренции и создавать равные условия для всех участников фармацевтического рынка. Развивая честную конкуренцию и разрабатывая прозрачные правила, государство будет способствовать снижению дефицита лекарственных средств, а также справедливым ценам на фармацевтическую продукцию.

Проблема высоких цен на лекарственные средства характерна для Казахстана уже многие годы. Начиная с 2009 года государство заключало меморандумы по сдерживанию цен на лекарственные средства с участниками фармацевтического рынка. Учитывая высокую импортную зависимость, неразвитость рынка в сельской местности, проблемы в сфере логистики, меморандумы не приносили должного эффекта. В этом же году государство создало единого дистрибьютора лекарств - ТОО «СК-Фармация». ${ }^{9}$ «СК-Фармация» была создана для обеспечения населения качественными и безопасными лекарствами, a также для экономии бюджетных средств посредством централизованной закупки лекарств. Именно неудовлетворительная деятельность «СК-Фармация» во время всемирной пандемии COVID-19, стала одной из причин нехватки лекарственных средств в Казахстане. После конструктивной критики Президента Казахстана К.К. Токаева, произошли структурные изменения в деятельности «СКФармация». Так в рамках программы «Перезагрузка» была создана рабочая группа из двадцати двух представителей общественности. На сайте «СК-Фармация» был создан раздел народный контроль. Рекомендации совета по противодействию коррупции и теневой экономики при Национальной палате предпринимателей «Атамекен», озвученные в 2016 году начали реализовываться только в 2021 году. ${ }^{11}$ Так в наблюдательном совете «СК-Фармация» стало больше представителей общественности и частных структур. Если в 2020 году из пяти представителей четверо работали в государственных и

\footnotetext{
${ }^{10}$ ЮРИСТ - Параграф. [Электронный ресурс]. URL: https://online.zakon.kz/Document/?doc $\mathrm{id}=36219777 \#$ pos $=3 ;-80$ (дата обращения: 2.03.2021).

${ }^{11}$ Решение Совета №3 от 19 сентября 2016 г. Национальная палата предпринимателей Казахстана Атамекен. [Электронный ресурс]. URL: https://atameken.kz/uploads/content/files/\%D $0 \%$ A $0 \%$ D0 $\%$ B $5 \%$ D $1 \% 88 \%$ D0 $\%$ B $5 \%$ D0 $\%$ BD $\%$ D $0 \% \mathrm{~B} 8 \% \mathrm{D} 0 \% \mathrm{~B} 5 \% 203 \% 20 \% \mathrm{D} 0 \% \mathrm{BE} \% \mathrm{D} 1 \% 82 \% 20$ 19 09_2016\%D0\%B3.pdf.pdf (дата обращения: 4.1̄2.2020).
} 
квазигосударственных структурах, то в 2021 году количество представителей государственного сектора в наблюдательном совете «СК-Фармация» сократилось до двух человек. Остальные представители наблюдательного совета «СК-Фармация» представляли Союз транспортников «KAZLOGISTICS», компанию «iKapitalist ltd» и общественный контроль. В то же время наблюдательные советы Республиканского центра развития здравоохранения и Национального центра экспертизы лекарственных средств и медицинских изделий состоят из 7 человек, представителей государственных органов, медицинских ассоциаций и компаний, медицинских образовательных учреждений.

Стоит отметить, что «СК-Фармация» была создана по малазийскому опыту («Фарманиага»), без учета различий стран в количестве и плотности населения, наличия дешевого водного транспорта у Малайзии и т.д. В большинстве стран Организации экономического сотрудничества и развития (ОЭСР) лекарственные средства закупаются страховыми медицинским фондами, так как лекарственные средства являются частью медицинского страхования. В 2020 году в Казахстане было внедрено обязательное социальное медицинское страхование и утверждены правила сооплаты на лекарственные средства и медицинские изделия. Поэтому возникает вопрос передачи функций ТОО «СК-Фармация» непосредственно Фонду социального медицинского страхования.

Во время пандемии COVID-19 были зафиксированы факты завышения цен на лекарственные средства. Президент Казахстана К.К. Токаев неоднократно давал поручения, направленные на снижение цен на лекарственные средства. Так 1 июля 2020 года с целью снижения ажиотажного спроса, государство временно ограничило продажу лекарств, аптеки в одни руки отпускали не более 3 упаковок. С целью выявления завышенных цен на лекарства, Министерство внутренних дел и прокуратура проводили рейды по розничным аптекам. В результате проверок, были выявлены факты завышения цен. Предельные цены на лекарства в оптовом и розничном сегменте были обновлены 11 июля 2020 года. Благодаря проекту «Адалдық алаңы» в розничных аптеках была размещена информация о предельных ценах на антиковидные лекарственные средства и контактные номера горячих линий. В целях предотвращения дефицита лекарств, «СКФармация» создала на своих хабах двухмесячный запас антиковидных лекарств. Так в городе Алматы было сосредоточено 35\% запаса лекарств, в городе Нур-Султан 30\%, в городе Актобе 15\% и в городе Шымкент 20\%. В медицинских учреждениях были сформированы двухмесячные запасы лекарственных средств. Несмотря на принимаемые меры, цены на лекарства по-прежнему оставались высокими для населения, в результате чего Правительство 31 декабря 2020 года обновила предельные цены и наценки на более чем 230 антиковидных лекарств. ${ }^{12}$ В результате данных мер, цены на антиковидные лекарства снизились на $27 \%$. В тоже время в результате анализа, были выявлены факты завышения цен на лекарственные средства дистрибьютора ми. Дистрибьюторы использовали самую высокую годовую цену из инвойсов, не всегда предоставляли цены производителей лекарств, а также в некоторых случаях закупали лекарства не у производителей, а у посредников, что в конечном счете сказывалось на ценах для казахстанских потребителей. Кроме этого, были выявлены факты, когда ответственные государственные органы не проверяли предоставленные дистрибьюторами цены заводов изготовителей лекарственных средств.

Государству необходимо взвешенно проводить политику ценообразования на лекарственные средства, зарубежный опыт показывает, что в случае проведения жесткой ценовой политики, есть риск дефицита и исчезновения лекарств [27]. Так уже в январе 2021 года жители Алматы начали жаловаться на отсутствие лекарств повышенного спроса в розничных аптеках города. Например, дефицитнымисталилекарства «Кардиомагнил», «Кипферон» и т.д. Для бесперебойного обеспечения населения необходимыми лекарствами, государству необходимо обдумано принимать административные меры по сдерживанию цен на лекарственные средства. Существуют различные методы определения цен на лекарственные средства, которые не ущемляют интересы населения и фармацевтических компаний.

Казахстан в 2015 году полностью перешел на внешнее референтное ценообразование на лекарственные средства в рамках гарантированного объема бесплатной меди-

\footnotetext{
12 Приказ МЗ № ҚР ДСМ-337/2020 от 31 декабря 2020 года О внесении изменений и дополнений в приказ Министра здравоохранения Республики Казахстан от 15 июля 2019 года № ҚР ДСМ-104 «Об утверждении предельных цен на торговое наименование лекарственного средства для розничной и оптовой реализации». [Электронный pecypc]. URL: https://adilet.zan.kz/rus/docs/ V2000022014 (дата обращения: 24.03.2021).
} 
цинской помощи (ГОБМП). В качестве референтных стран использовались основные страны (Беларусь, Венгрия, Латвия, Чехия) и резервные страны (Австрия, Россия, Турция, Украина). Также для определения цен, использовалась международная база цен и Британский национальный лекарственный формуляр ${ }^{13}$. Референтные страны выбирались по схожему уровню жизни и c учетом единого экономического пространства. При этом ВВП Австрии на душу населения в 2015 году составлял 44178 USD, а ВBП Казахстана на душу населения составлял 10510 USD. Цены на лекарства не должны были превышать предельные цены установленные законодательством. Кроме внешнего референтного ценообразования, использовались механизмы внутреннего референтного ценообразования и переговоры с производителями лекарственных средств.

В 2018 году Казахстан изменил свою референтную корзину стран. Казахстанская корзина включала в себя 35 стран и была самой большой среди стран ЕАЭС, ЕС и ОЭСР. В случае невозможности определить цену в референтной стране, использовались альтернативные страны где была зарегистрирована цена на лекарство. Предельные цены формировались в рамках ГОБМП и в системе обязательного социального медицинского страхования (ОСМС). ${ }^{14}$

Таблица 1 - Внешняя референтная корзина Республики Казахстан в 2015-2019 годах

Table 1-External reference basket of the Republic of Kazakhstan in 2015-2019

\begin{tabular}{|c|c|c|c|c|c|c|}
\hline № & \begin{tabular}{|c|} 
Внешняя \\
референтная корзина \\
РК в 2015 году (ВВП \\
на душу населения в
\end{tabular} & $\begin{array}{c}\text { Внешняя } \\
\text { референтная } \\
\text { корзина РК в } 2018\end{array}$ & \multicolumn{4}{|c|}{$\begin{array}{l}\text { Внешняя референтная корзина РК в } 2019 \text { году } \\
\text { (ВВП на душу населения в USD) }\end{array}$} \\
\hline 1 & Беларусь (5 949) & \multirow{9}{*}{$\begin{array}{c}\text { Всего } 35 \text { стран: } \\
4 \text { страны ЕАЭС } \\
\text { и страны ОЭСР } \\
\text { (кроме Колумбии, } \\
\text { Коста-Рики, } \\
\text { США, Словакии, } \\
\text { Словении, Турции, } \\
\text { Литвы) }\end{array}$} & 1 & Азербайджан (4 480) & 9 & Россия (11 585) \\
\hline 2 & Венгрия (12 706) & & 2 & Беларусь (6 663) & 10 & Румыния (12 919) \\
\hline 3 & Латвия (13 774) & & 3 & Болгария (9 828) & 11 & Словакия (19 266) \\
\hline 4 & Чехия (17 829) & & 4 & Венгрия (16 731) & 12 & Словения (25 946) \\
\hline 5 & Австрия (44 178) & & 5 & Греция (19 582) & 13 & Турция (9 126) \\
\hline 6 & Россия (9 313) & & 6 & Латвия (17 828) & 14 & Хорватия (14 936) \\
\hline 7 & Турция (11 006) & & 7 & Литва (19 601) & 15 & Чехия (23 494) \\
\hline 8 & Украина (2 124) & & 8 & Польша (15 692) & 16 & Эстония (23 723) \\
\hline & & & & Страна прои & тель & екарства \\
\hline
\end{tabular}

Примечание - Составлена авторами.

13 Приказ Министерства здравоохранения и социального развития Республики Казахстан от 30 июля 2015 года № 639 «Правила формирования предельных цен и наценок на лекарственные средства и изделия медицинского назначения, закупаемых в рамках гарантированного объема бесплатной медицинской помощи и в системе обязательного социального медицинского страхования». [Электронный ресурс]. URL: https://adilet.zan.kz/rus/docs/V1500011887 (дата обращения: 10.01.2021).

14 Фоглер С., Циммерманн Н. (2020). Отчет Информационной сети по ценообразованию и возмещению стоимости лекарств для Восточной Европы и Центральной Азии; ВО3, Европейское региональное бюро. [Электронный ресурс]. URL: https://www.euro.who.int/_data/assets/pdf file/0007/455938/Pharmaceutical-pricing-eng.pdf (дата обращения: 20.05.2021).
C апреля 2019 года цены начали регулироваться как в ГОБМП и ОСМС, так и в оптовой и в розничной торговле. Референтная корзина стран снова была пересмотрена и сокращена с 35 до 16 стран $^{15}$. В корзину не были включены партнеры по ЕАЭС, Армения и Кыргызстан. Казахстан начал дополнительно использовать критерий «страна производитель» лекарства. Из 16 стран, 11 стран обладали высоким уровнем дохода и только 3 страны уступали Казахстану (9 812 USD) по показателю ВВП на душу населения. Меняя страны в референтной

\footnotetext{
${ }^{15}$ Приказ Министерства здравоохранения Республики Казахстан от 19 апреля 2019 года № ҚР ДСМ-42 «Об утверждении Правил регулирования цен на лекарственные средства». [Электронный pecypc]. URL: https://adilet.zan.kz/rus/docs/ V1900018573 (дата обращения: 5.04.2021).
} 
корзине, Казахстан не придерживается международных рекомендаций по составлению внешней референтной корзины [28,29].

B период всемирной пандемии COVID-19 цены на лекарственные средства продолжили свой рост. Научные исследования и зарубежный опыт показывают, что включение в референтную корзину стран с высоким уровнем доходов будет способствовать увеличению цен. Если страна включает в свою референтную корзину страны с более низкими доходами, то цены будут снижаться [30]. Поэтому целесообразно пересмотреть страны в референтной корзине, например, добавить Армению и Кыргызстан, с данными странами у Казахстана функционирует единый фармацевтический рынок. Мировой опыт показывает, что развитые страны мира, используют внешнее референтное ценообразование как один из методов определения цен или как дополнение во время переговоров по определению цен на лекарства $[31,32,33]$. Созрела необходимость рассмотреть, другие методы ценообразования, например «издержки плюс прибыль», «ценообразование по результатам» и т.д.

Высокие цены и дефицит лекарственных средств, негативно сказываются на населении, поэтому государству необходимо принимать действенные меры по решению указанных проблем. В период пандемий или форсмажорных ситуаций, государство должно обладать широкими возможностями регулировать цены на социально важные лекарственные средства. Развитые страны ОЭСР широко используют различные инструменты определения цен на лекарственные средства. Например, чтобы определить цены на лекарства генерики, зачастую используют внутреннее референтное ценообразование, цены патентованных лекарств определяют методом внешнего референтного ценообразования, цены на инновационные лекарства определяют методом оценки ценности лекарств. Определенные страны регулируют норму прибыли, определяют цену лекарства исходя из ценности, используют схемы альтернативного ценообразования или используют смешанные схемы ценообразования [34].

Республика Казахстан поставила перед собой задачу к 2025 году сократить расходы казахстанцев с $42 \%$ до $30 \%$ на здравоохранение, в том числе и расходы на лекарственные средства. Согласно рекомендациям ВОЗ доля расходов населения на здравоохранение не должна превышать $20 \%$ от общих расходов. ${ }^{1}$ Системы здравоохранения стран, где расходы населения на здравоохранение не превышают $20 \%$, считаются устойчивыми. Последствия всемирной пандемии COVID-19 и инфляция болезненно сказались на расходах казахстанцев. В период пандемии расходы казахстанцев на лекарства, медицинские изделия и медицинскую технику увеличились на $63 \%$. За 2020 год в среднем каждое домашнее хозяйство потратило на лекарства, медицинские изделия и технику 47,1 тыс. тенге. Больше всех расходовали в городе Алматы $(71,7$ тыс. тенге), меньше всех в Кызылординской области $\left(29,8\right.$ тыс. тенге). ${ }^{3}$ Большие расходы населения характерная проблема для Казахстана уже многие годы. Так в структуре расходов на здравоохранение за 2018 год, казахстанцы больше всего тратили на лекарственные средства $(60,7 \%)$. На душу населения частные расходы на лекарства составили 19356 тыс. тенге, государственные расходы 5213 тыс. тенге. Общие расходы на лекарства составили 24569 тыс. тенге (70 USD). В странах ОЭСР расходы население на лекарства в 2018 году составляли $38,1 \%$ в общих расходах на здравоохранение, а расходы на лекарства на душу населения составляли 376,7 USD [35].

Государству необходимо предпринимать меры по решению проблем связанных с дефицитом лекарств, высоких цен на фармацевтическую продукцию и больших расходов населения на здравоохранение. Внедрение системы OCMC, системы соплатежей на лекарства, увеличение финансирования системы здравоохранения, регулирование цен на все виды лекарств и т.д., не в полной мере смогли решить вышеперечисленные проблемы во время пандемии COVID-19. Казахстану необходимы структурные реформы, созрела необходимость изменения государственного управления в сфере обращения лекарственных средств. Пандемия COVID-19 показала уязвимость в работе единого дистрибьютора лекарственных средств и высокую зависимость от импорта фармацевтической продукции. Увеличение количества эпидемий (свинной и птичий грипп, SARS, лихорадка Эболла и т.д.) с 2000 года показывает что государствам необходимо эффективно выстраивать системы здравоохранения и сферы обращения лекарственных средств. С каждым годом, именно от эффективности государственного управления системой здравоохранения и сферой обращения лекарственных средств будет зависеть здоровье и жизнь граждан, в целом национальная безопасность государства. 


\section{Заключение}

Результаты, полученные в ходе проведенного исследования, позволили сделать следующие выводы:

1. Казахстану необходимо уменьшать импортную зависимость от иностранных лекарств. Во время пандемии COVID-19, Казахстан не смог обеспечить лекарственную безопасность, производя только 17\% лекарств (в денежном выражении). В указанный период более 20 стран и ряд международных организаций отправили в Казахстан гуманитарную помощь в виде лекарств. Поэтому государству необходимо создавать благоприятные условия, как для казахстанских, так и для иностранных производителей лекарств. Необходимо также привлекать компании из «Big Pharma», для локализации производства в Казахстане. Стоит рассмотреть вариант, предоставления казахстанским компаниям налоговых каникул и льготного кредитования. Необходимо поощрять казахстанские компании, использующие «контрактное производство» и упростить излишние бюрократические процедуры. Например, признавать клинические исследования, проведенные не только в странах ICH (EC, Великобритания, Швейцария, Канада, США, Япония) но и в Норвегии, Исландии, Израиле, Южной Кореи, Австралии и Новой Зеландии. Также необходимо упростить процедуру экспертизы и регистрации для социально важных лекарств, произведенных по стандартам GMP в приоритетных странах. Кроме того, лекарства, произведенные по стандартам GMP не должны проходить процедуру оценки качества.

2. Государству необходимо создавать равные условия для всех участников фармацевтического рынка. Лоббирование интересов, каких либо компаний должно быть недопустимым явлением. Честная конкуренция вынуждает повышать качество работы фармацевтических компаний и снижать цены на свои услуги и продукцию. В разгар пандемии COVID-19, множество компаний проявляли инициативу и старались оперативно решать форс-мажорные ситуации, возникшие изза дефицита лекарств. Дополнительные логистические услуги оказывала дистрибьюторская компания «INKAR», ведущие казахстанские производители лекарств дополнительно увеличили производство фармацевтической продукции. Пандемия COVID-19 показала, как важно на фармацевтическом рынке иметь множество сильных фармацевтических компаний.
3. Первые попытки внедрить внешнее референтное ценообразование в Казахстане были предприняты в 2013 году. Полностью данный вид ценообразования заработал в 2015 году. Недостаточно хорошо изучив мировой опыт, Казахстан менял референтную корзину в 2018 и 2019 году. Внешнее референтное ценообразование не используется в Великобритании, США, Швеции, Чили. Во многих развитых странах ОЭСР метод внешнего референтного ценообразования не является основным методом определения цен на лекарственные средства, во многом из-за минусов внешнего референтного ценообразования. Казахстан в своей референтной корзине в основном использует страны с высоким уровнем доходов. Последние тренды показывают, что страны (Япония, Канада, Нидерланды) стараются не использовать в своих референтных корзинах государства с высокими доходами и высокими ценами на лекарства. При выборе референтной корзины, страны стараются использовать критерии географическая близость и тесные экономические связи. Данные критерии были проигнорированы Казахстаном при составлении внешней референтной корзины в 2019 году.

4. Чтобы сократить большие расходы населения на лекарственные средства, необходимо использовать альтернативные методы ценообразования. По примеру стран ОЭСР, можно использовать смешанные методы ценообразования, так как у каждого метода есть свои недостатки и преимущества. В рамках единого фармацевтического рынка, странам ЕАЭС будет выгодно совместно закупать лекарственные средства, например орфанные препараты. Совместные закупки будут способствовать снижению цен на лекарственные средства [36,37]. Кроме этого, тобы снизить расходы населения на здравоохранение до $20 \%$, государству необходимо увеличить финансирование системы здравоохранения до уровня стран ОЭСР. Несомненно, внедрение ОСМС и соплатежей будет снижать уровень расходов населения, но без увеличения государственного финансирования добиться необходимых показателей BO3 будет невозможно. Стоит отметить что средний показатель затрат на систему здравоохранения в странах ОЭСР в 2018 году составлял $8,8 \%$ к ВВП $(6,6 \%$ государственные расходы; 2,2\% частные расходы), в Казахстане данный показатель был равен 2,9\% к ВВП(1,7\% государственные расходы; частные расходы $1,2 \%)$. 


\section{Список использованных источников}

1. Bochenek, T., Abilova, V., Alkan, A., Asanin, B., de Miguel Beriain, I., Besovic, Z., Vella Bonanno, P., Bucsics, A., Davidescu, M., De Weerdt, E., Duborija-Kovacevic, N., Fürst, J., Gaga, M., Gailīte, E., Gulbinovič, J., Gürpınar, E. U., Hankó, B., Hargaden, V., Hotvedt, T. A., Hoxha, I., \& Godman, B. (2018). Systemic Measures and Legislative and Organizational Frameworks Aimed at Preventing or Mitigating Drug Shortages in 28 European and Western Asian Countries. Frontiers in pharmacology, 8, 942. https:// doi.org/10.3389/fphar.2017.00942

2. Acosta, A., Vanegas, E. P., Rovira, J., Godman, B., \& Bochenek, T. (2019). Medicine Shortages: Gaps Between Countries and Global Perspectives. Frontiers in pharmacology, 10, 763. https://doi.org/10.3389/ fphar.2019.00763

3. Badreldin, H.A., \& Atallah, B. (2021). Global drug shortages due to COVID-19: Impact on patient care and mitigation strategies. Research in social \& administrative pharmacy: RSAP, 17(1), 1946-1949. https://doi.org/10.1016/j.sapharm.2020.05.017

4. Vogler, S., \& Fischer, S. (2020). How to address medicines shortages: Findings from a cross-sectional study of 24 countries. Health policy, 124(12), 12871296. https://doi.org/10.1016/j.healthpol.2020.09.001

5. Shuman, A.G., Fox, E., \& Unguru, Y. (2020). Preparing for COVID-19-related Drug Shortages. Annals of the American Thoracic Society, 17(8), 928-931. https://doi.org/10.1513/AnnalsATS.202004$362 \mathrm{VP}$

6. Pisani, E., Nistor, A. L., Hasnida, A., Parmaksiz, K., Xu, J., \& Kok, M. O. (2019). Identifying market risk for substandard and falsified medicines: an analytic framework based on qualitative research in China, Indonesia, Turkey and Romania. Wellcome open research, 4, 70. https://doi.org/10.12688/ wellcomeopenres. 15236.1

7. Зординова, К. А. (2015). Проблема фальсифицированных и субстандартных лекарственных средств в мире и в Казахстане. Вестник Казахского национального медицинского университета, 1, 459-464.

8. Торопыгин, А. В. (2018). Политикоправовые аспекты формирования регионального рынка лекарств Евразийского экономического союза. Евразийская интеграция: экономика, право, политика, 2(24), 98-107.

9. Торегожина, М. Б. (2019). Конкурентоспособность химико-фармацевтической отрасли Республики Казахстан в рамках ЕАЭС. Статистика, учет и аудит, 3(74), 223-227.

10. Марцева, Т. Г., Воблая, И. Н., Сейфиева, Е. Н. (2019). Особенности регулирования фармацевтического рынка Евразийского экономического союза. Проблемы социальной гигиены, здравоохранения и истории медицины, 27 (5), 841-846. https://doi.org/10.32687/0869866X-2019-27-5-841-846

11. Бортникова, А. П. (2018). Формирование общего фармацевтического рынка ЕАЭС: проблемы и их решения. Евразийский юридический журнал, 8(123), 19-21.
12. Дюсембинова, Г. А., Искакова, Б. З., Серикбаева, Э. А., Дошманова. С. Д. (2020). Фармацевтический рынок Казахстана в условиях внедряемой политики нормативного правового регулирования. Фармация Казахстана, 3, 45-48.

13. Джилиссен, Э., Маллиган, К., Тоттман, С., Троен. П. (2020). Гибкое управление запасами: страхование поставок лекарственных средств. Ремедиум. Журнал о российском рынке лекарств и медицинской техники. 11(12), 4-17. https://doi. org/10.21518/1561-5936-2020-11-12-4-17

14. Акимов, А. В. (2021). Роль ВОЗ в борьбе c COVID-19. Итоги первого года. Международная жизнь, 5, 16-31.

15. Mallah, S. I., Ghorab, O. K., Al-Salmi, S., Abdellatif, O. S., Tharmaratnam, T., Iskandar, M. A., Sefen, J., Sidhu, P., Atallah, B., El-Lababidi, R., \& Al-Qahtani, M. (2021). COVID-19: breaking down a global health crisis. Annals of clinical microbiology and antimicrobials, 20(1), 35. https://doi.org/10.1186/ s12941-021-00438-7

16. Haug, N., Geyrhofer, L., Londei, A. et al. (2020). Ranking the effectiveness of worldwide COVID-19 government interventions. Nat Hum Behav 4, 1303-1312. https://doi.org/10.1038/s41562-02001009-0

17. Brauner, J.M., Mindermann, S., Sharma, M., Johnston, D., Salvatier, J., Gavenčiak, T., Stephenson, A. B., Leech, G., Altman, G., Mikulik, V., Norman, A. J., Monrad, J. T., Besiroglu, T., Ge, H., Hartwick, M. A., Teh, Y. W., Chindelevitch, L., Gal, Y., \& Kulveit, J. (2021). Inferring the effectiveness of government interventions against COVID-19. Science, 371(6531):eabd9338. https://doi.org/ 10.1126/science. abd 9338

18. Shah, S., Ray, B., Holy, C., Sakthivel, M., Elangovanraaj, N., Krishnan, D., Gupta, S., Trivedi, P., Devulapally, M., Mohapatra, A., \& Coplan, P. (2020). IN3 Impact of Government Measures on COVID-19 Incidence of Reported New Cases: An Analysis of 9 Countries. Value in Health, 23, S403. https://doi. org/10.1016/j.jval.2020.08.038

19. Терещенко, А. П. (2020). Обеспечение лекарственной независимости как фактор экономической и национальной безопасности государства. Гуманитарные, социальноэкономические и общественные науки, 12(1), 162165. https://doi.org/10.23672/c1758-0305-6989-g

20. Сатаева, Л. Г., Мырзабаева, Н. А., Шопабаева А. Р. (2019). Современная система закупок лекарственных средств больным социально значимыми заболеваниями в Казахстане. Психическое здоровье, 2, 13-17. https://doi. org/10.25557/2074-014X.2019.02.13-17

21. Жусупова, Г. К., Сквирская, Г. П., Есбатырова, Л. М., Байдуллаева, Д. К., Калиева, Ш. С. (2019). Обзор системы лекарственного обеспечения населения Казахстана и использования лекарственных средств на амбулаторном уровне. Современные проблемы здравоохранения и медицинской статистики, 4, 327-345.

22. Aliyeva, N. A., Manap, A. S., \& Issabayev, M. M. (2020). Kazakhstan's pharmaceutical market in the context of global trends. Экономическая серия 
Вестника ЕНУ им. Л.Н. Гумилева, 4, 21-35. https:// doi.org/10.32523/2079-620X-2020-4-21-35

23. Кульжанов, М. К., Жантуриев, Б. М., Надыров, П. Т. (2019). Роль НЦЭЛС в лекарственном обеспечении населения Казахстана. Вестник Казахского национального медицинского университета, 1, 644-646.

24. Спанов, М. У. (2019). Конкурентоспособность и развитие фармацевтической промышленности Казахстана. Экономика: стратегия и практика, 14 (3), 69-84.

26. Датхаев, У. М., Шопабаева, А. Р., Ержанова, Р. Б. (2019). Анализ деятельности фармацевтических дистрибьюторов Республики Казахстан. Социальная аптека в здравоохранении, 5 (1), 41-48. https://doi. org/10.24959/sphhcj.19.143

27. David, I. Preţul mediu al unei cutii de medicamente s-a dublat în ultimii şapte ani. Ziarul Financiar. 2012; Accessed 26 Jul 2018. Reference Source.

28. Seung-Lai, Yoo., Dae-Jung, Kim., Seung-Mi, Lee., Won-Gu, Kang., Sang-Yoon, Kim., Jong Hyuk, Lee., Dong-Churl, Suh. (2019). Improving Patient Access to New Drugs in South Korea: Evaluation of the National Drug Formulary System. International Journal of Environmental Research and Public HealthOpen Access Journal, 16, 288.

29. Habl, C., Schneider, P., Sebesta, R., \& Németh, G. (2018). Euripid Collaboration Guidance Principles for External Reference Pricing in Europe. European Journal of Public Health, 28 (4). https://doi. org/10.1093/eurpub/cky212.217

30. LSE Health, Medical Technology Research Group: Survey of key experts on the regulation of medical technology. http://www.lse.ac.uk/lse-health/ research/mtrg (2017).

31. Espin, J., Rovira, J., \& Olry de Labry, A. (2019). External reference pricing. WHO. Health Action International. [Electronic resource]. URL: http://www.haiweb.org/medicineprices/24072012/ ERPfinalMay2011.pdf (date of access: 6.08.2019).

32. Stargardt, T., \& Schreyögg, J. (2006). Impact of cross-reference pricing on pharmaceutical prices. manufacturers' pricing strategies and price regulation. Appl Health Econ Health Policy, 5(4), 235-47.

33. Persson, U., \& Jonsson, B. (2016). The end of the international reference pricing system? Appl Health Econ Health Policy, 14(1), 1-8.

34. Espin, J., Rovira, J., Ewen, M., \& Laing, R. (2014). WHO/HAI Project on Medicines Prices and Availability. Review Series on Pharmaceutical Pricing Policies and Interventions. Working Paper 1: External price referencing. Andalusian School of Public Health.

35. Загидуллина, Г. Н., Омирбаева, Б. С. Анализ частных расходов на здравоохранение в Казахстане и предложения по их снижению. Аналитический обзор для формирования политики (Policy Brief), Нур-Султан: Республиканский центр развития здравоохранения, 2019, С.20.

36. Eatwell, E., \& Swierczyna, A. (2019). Emerging voluntary cooperation between European healthcare systems: Are we facing a new future? Medicine Access @ Point of Care. https://doi. org/10.1177/2399202619852317.
37. Kohler, J.C., Mitsakakis, N., Saadat, F., Byng, D., \& Martinez, M.G. (2015). Does Pharmaceutical Pricing Transparency Matter? Examining Brazil's Public Procurement System. Glob Health, 11, 34-0150118-8.25

\section{References:}

1. Bochenek, T., Abilova, V., Alkan, A., Asanin, B., de Miguel Beriain, I., Besovic, Z., Vella Bonanno, P., Bucsics, A., Davidescu, M., De Weerdt, E., Duborija-Kovacevic, N., Fürst, J., Gaga, M., Gailīte, E., Gulbinovič, J., Gürpınar, E. U., Hankó, B., Hargaden, V., Hotvedt, T. A., Hoxha, I., \& Godman, B. (2018). Systemic Measures and Legislative and Organizational Frameworks Aimed at Preventing or Mitigating Drug Shortages in 28 European and Western Asian Countries. Frontiers in pharmacology, 8, 942. https:// doi.org/10.3389/fphar.2017.00942

2. Acosta, A., Vanegas, E. P., Rovira, J., Godman, B., \& Bochenek, T. (2019). Medicine Shortages: Gaps Between Countries and Global Perspectives. Frontiers in pharmacology, 10, 763. https://doi.org/10.3389/ fphar.2019.00763

3. Badreldin, H. A., \& Atallah, B. (2021). Global drug shortages due to COVID-19: Impact on patient care and mitigation strategies. Research in social \& administrative pharmacy: RSAP, 17(1), 1946-1949. https://doi.org/10.1016/j.sapharm.2020.05.017

4. Vogler, S., \& Fischer, S. (2020). How to address medicines shortages: Findings from a cross-sectional study of 24 countries. Health policy, 124(12), 12871296. https://doi.org/10.1016/j.healthpol.2020.09.001

5. Shuman, A. G., Fox, E., \& Unguru, Y. (2020). Preparing for COVID-19-related Drug Shortages. Annals of the American Thoracic Society, 17(8), 928931. https://doi.org/10.1513/AnnalsATS.202004$362 \mathrm{VP}$

6. Pisani, E., Nistor, A. L., Hasnida, A., Parmaksiz, K., Xu, J., \& Kok, M. O. (2019). Identifying market risk for substandard and falsified medicines: an analytic framework based on qualitative research in China, Indonesia, Turkey and Romania. Wellcome open research, 4, 70. https://doi.org/10.12688/ wellcomeopenres. 15236.1

7. Zordinova, K. A. (2015). Problema fal'sificirovannyh i substandartnyh lekarstvennyh sredstv v mire i v Kazahstane. Vestnik Kazahskogo nacional'nogo medicinskogo universiteta, 1, 459-464.

8. Toropygin, A. V. (2018). Politiko-pravovye aspekty formirovanija regional'nogo rynka lekarstv Evrazijskogo jekonomicheskogo sojuza. Evrazijskaja integracija: jekonomika, pravo, politika, 2(24), 98-107.

9. Toregozhina, M. B. (2019). Konkurentosposobnost' himiko-farmacevticheskoj otrasli Respubliki Kazahstan v ramkah EAJeS. Statistika, uchet $i$ audit, 3(74), 223-227.

10. Marceva, T. G., Voblaja, I. N., Sejfieva, E. N. (2019). Osobennosti regulirovanija farmacevticheskogo rynka Evrazijskogo jekonomicheskogo sojuza. Problemy social'noj gigieny, zdravoohranenija i istorii mediciny, 27 (5), 841-846. https://doi.org/10.32687/0869$866 \mathrm{X}-2019-27-5-841-846$ 
11. Bortnikova, A. P. (2018). Formirovanie obshhego farmacevticheskogo rynka EAJeS: problemy i ih reshenija. Evrazijskij juridicheskij zhurnal, 8(123), 19-21.

12. Djusembinova, G. A., Iskakova, B. Z., Serikbaeva, Je. A., Doshmanova. S. D. (2020). Farmacevticheskij rynok Kazahstana $\mathrm{v}$ uslovijah vnedrjaemoj politiki normativnogo pravovogo regulirovanija. Farmacija Kazahstana, 3, 45-48.

13. Dzhilissen, Je., Malligan, K., Tottman, S., Troen. P. (2020). Gibkoe upravlenie zapasami: strahovanie postavok lekarstvennyh sredstv. Remedium. Zhurnal o rossijskom rynke lekarstv $i$ medicinskoj tehniki. 11(12), 4-17. https://doi.org/10.21518/15615936-2020-11-12-4-17

14. Akimov, A. V. (2021). Rol' VOZ v bor'be s COVID-19. Itogi pervogo goda. Mezhdunarodnaja zhizn', 5, 16-31.

15. Mallah, S. I., Ghorab, O. K., Al-Salmi, S., Abdellatif, O. S., Tharmaratnam, T., Iskandar, M. A., Sefen, J., Sidhu, P., Atallah, B., El-Lababidi, R., \& Al-Qahtani, M. (2021). COVID-19: breaking down a global health crisis. Annals of clinical microbiology and antimicrobials, 20(1), 35. https://doi.org/10.1186/ s12941-021-00438-7

16. Haug, N., Geyrhofer, L., Londei, A. et al. (2020). Ranking the effectiveness of worldwide COVID-19 government interventions. Nat Hum Behav 4 , 1303-1312. https://doi.org/10.1038/s41562-02001009-0

17. Brauner, J. M., Mindermann, S., Sharma, M., Johnston, D., Salvatier, J., Gavenčiak, T., Stephenson, A. B., Leech, G., Altman, G., Mikulik, V., Norman, A. J., Monrad, J. T., Besiroglu, T., Ge, H., Hartwick, M.A., Teh, Y. W., Chindelevitch, L., Gal, Y., \& Kulveit, J. (2021). Inferring the effectiveness of government interventions against COVID-19. Science, 371(6531):eabd9338. https://doi.org/ 10.1126/science.abd9338

18. Shah, S., Ray, B., Holy, C., Sakthivel, M., Elangovanraaj, N., Krishnan, D., Gupta, S., Trivedi, P., Devulapally, M., Mohapatra, A., \& Coplan, P. (2020). IN3 Impact of Government Measures on COVID-19 Incidence of Reported New Cases: An Analysis of 9 Countries. Value in Health, 23, S403. https://doi. org/10.1016/j.jval.2020.08.038

19. Tereshhenko, A. P. (2020). Obespechenie lekarstvennoj nezavisimosti kak faktor jekonomicheskoj i nacional'noj bezopasnosti gosudarstva. Gumanitarnye, social'no-jekonomicheskie $i$ obshhestvennye nauki, 12(1), 162-165. https://doi.org/10.23672/c1758-03056989-g

20. Sataeva, L. G., Myrzabaeva, N. A., Shopabaeva A. R. (2019). Sovremennaja sistema zakupok lekarstvennyh sredstv bol'nym social'no znachimymi zabolevanijami v Kazahstane. Psihicheskoe zdorov'e, 2, 13-17. https://doi.org/10.25557/2074014X.2019.02.13-17

21. Zhusupova, G. K., Skvirskaja, G. P., Esbatyrova, L. M., Bajdullaeva, D. K., Kalieva, Sh. S. (2019). Obzor sistemy lekarstvennogo obespechenija naselenija Kazahstana i ispol'zovanija lekarstvennyh sredstv na ambulatornom urovne. Sovremennye problemy zdravoohranenija $i$ medicinskoj statistiki, 4, 327-345.
22. Aliyeva, N. A., Manap, A. S., \& Issabayev, M. M. (2020). Kazakhstan's pharmaceutical market in the context of global trends. Jekonomicheskaja serija Vestnika ENU im. L.N. Gumileva, 4, 21-35. https://doi. org/10.32523/2079-620X-2020-4-21-35

23. Kul'zhanov, M. K., Zhanturiev, B. M., Nadyrov, P. T. (2019). Rol' NCJeLS v lekarstvennom obespechenii naselenija Kazahstana. Vestnik Kazahskogo nacional'nogo medicinskogo universiteta, 1, 644-646.

24. Spanov, M. U. (2019). Konkurentosposobnost' i razvitie farmacevticheskoj promyshlennosti Kazahstana. Jekonomika: strategija i praktika, 14 (3), 69-84.

26. Dathaev, U. M., Shopabaeva, A. R., Erzhanova, R. B. (2019). Analiz dejatel'nosti farmacevticheskih distrib'jutorov Respubliki Kazahstan. Social'naja apteka $v$ zdravoohranenii, 5 (1), 41-48, https://doi. org/10.24959/sphhcj.19.143

27. David, I. Preţul mediu al unei cutii de medicamente s-a dublat în ultimii şapte ani. Ziarul Financiar. 2012; Accessed 26 Jul 2018.

28. Seung-Lai, Yoo., Dae-Jung, Kim., Seung-Mi, Lee., Won-Gu, Kang., Sang-Yoon, Kim., Jong Hyuk, Lee., Dong-Churl, Suh. (2019). Improving Patient Access to New Drugs in South Korea: Evaluation of the National Drug Formulary System. International Journal of Environmental Research and Public HealthOpen Access Journal, 16, 288.

29. Habl, C., Schneider, P., Sebesta, R., \& Németh, G. (2018). Euripid Collaboration Guidance Principles for External Reference Pricing in Europe. European Journal of Public Health, 28 (4). https://doi. org/10.1093/eurpub/cky212.217

30. LSE Health, Medical Technology Research Group: Survey of key experts on the regulation of medical technology. http://www.lse.ac.uk/lse-health/ research/mtrg (2017).

31. Espin, J., Rovira, J., \& Olry de Labry, A. (2019). External reference pricing. WHO; Health Action International. [Electronic resource]. URL: http://www.haiweb.org/medicineprices/24072012/ ERPfinalMay2011.pdf (date of access: 6.08.2019).

32. Stargardt, T., \& Schreyögg, J. (2006). Impact of cross-reference pricing on pharmaceutical prices. manufacturers' pricing strategies and price regulation. Appl Health Econ Health Policy, 5(4), 235-47.

33. Persson, U., \& Jonsson, B. (2016). The end of the international reference pricing system? Appl Health Econ Health Policy, 14(1), 1-8.

34. Espin, J., Rovira, J., Ewen, M., \& Laing, R. (2014). Espin, J., Rovira, J., Ewen, M., \& Laing, R. (2014). WHO/HAI Project on Medicines Prices and Availability. Review Series on Pharmaceutical Pricing Policies and Interventions. Working Paper 1: External price referencing. Andalusian School of Public Health.

35. Zagidullina, G. N., Omirbaeva, B. S. Analiz chastnyh rashodov na zdravoohranenie v Kazahstane i predlozhenija po ih snizheniju. Analiticheskij obzor dlja formirovanija politiki (Policy Brief), Nur-Sultan: Respublikanskij centr razvitija zdravoohranenija, 2019, P.20. 
36. Eatwell, E., \& Swierczyna, A. (2019). Emerging voluntary cooperation between European healthcare systems: Are we facing a new future? Medicine Access @ Point of Care. https://doi. org/10.1177/2399202619852317.

37. Kohler, J. C., Mitsakakis, N., Saadat, F., Byng, D., \& Martinez, M. G. (2015). Does Pharmaceutical Pricing Transparency Matter? Examining Brazil's Public Procurement System. Glob Health, 11, 34-0150118-8.25

\section{Information about the authors}

* Yerik B. Bukatov - Correspondent author, doctoral student, Karaganda university of Kazpotrebsoyuz, Kazakhstan, e-mail: bukatov.erik@mail.ru. ORCID ID: https://orcid.org/0000-0003-0513-406X

Galiya I. Gimranova - Candidate of Economic Sciences., professor, Karaganda university of Kazpotrebsoyuz, Kazakhstan, e-mail: Gimranovagalia@,mail.ru. ORCID ID: https://orcid.org/0000-0003-2378-9713

Sergey A. Shanin - Doctor of Economics, Professor, Plekhanov Russian University of Economics, Russia, e-mail: sershanin@rambler.ru.. ORCID ID: https://orcid.org/0000-0003-2403-4005

\section{Авторлар туралы мәліметтер}

* Букатов Е.Б. - докторант, Қазтұтынуодағы Қарағанды университеті, Қазақстан, e-mail: bukatov.erik@mail.ru. ORCID ID: https://orcid.org/0000-0003-0513-406X

Гимранова Г.И. - э.ғ.к., профессор, Қазтұтынуодағы Қарағанды университеті, Қазақстан, е-таil: Gimranovagalia@mail.ru._ORCID ID: https://orcid.org/0000-0003-2378-9713

Шанин С.А. - экономика ғылымдарының докторы, профессор, Г.В. Плеханов атындағы Ресей экономикалық университеті, e-mail: sershanin@rambler.ru. ORCID ID: https://orcid.org/0000-0003-2403-4005

\section{Сведения об авторах}

* Букатов Е.Б. - докторант, Карагандинский университет Казпотребсоюза, Казахстан, e-mail: bukatov.erik@, mail.ru. ORCID ID: https://orcid.org/0000-0003-0513-406X

Гимранова Г.И. - к.э.н., профессор, Карагандинский университет Казпотребсоюза, Казахстан, е-таil: Gimranovagalia@mail.ru._ORCID ID: https://orcid.org/0000-0003-2378-9713

Шанин С.А. - Д.э.н., профессор, Российский экономический университет имени Г.В. Плеханова, Россия , e-mail: sershanin@,rambler.ru. ORCID ID: https://orcid.org/0000-0003-2403-4005 